\title{
Exploring the Influence of English Subject Reform in China's Compulsory Education System
}

\author{
Maojia Sun ${ }^{1, \dagger}$, Kaiyi $\mathrm{Wu}^{2, *}{ }^{*}$, Xiaohan $\mathrm{Yi}^{3, \dagger}$, Ruohong Zhang ${ }^{4, \dagger}$ \\ ${ }^{1}$ Faculty of Educational Studies, Universiti Putra Malaysia, Selangor, 43400, Malaysia \\ ${ }^{2}$ School of Education, University of Sydney, Sydney, 2006, Australia \\ ${ }^{3}$ Communication and Media, University College London, London, WC1E6BT, UK \\ ${ }^{4}$ Letter and Science College, University of California, Davis, 95616, USA \\ *Corresponding author. Email: ${ }^{2}$ kawu7147@uni.sydney.edu.au \\ Those authors contributed equally.
}

\begin{abstract}
This paper aims to address the policy reform debate on whether English will continue to be the only mandatory foreign language subject in China's compulsory education system. It explores the role of English as a compulsory subject in China's nine-year compulsory education system and critically reflects the need for English as a compulsory subject in China. This paper presents three research questions: 1) what do learners think about the importance of English in China? 2) What are learners' motivations for learning English in China? 3) What is the learner's attitude towards English learning? This paper studies three questions and uses a qualitative research method to conduct a oneto-one interview with six graduate students who have received nine years of compulsory education in China. The results of the research mainly focus on three aspects: English language's status in China and its impacts, two English learning motivations, learners' attitudes towards English subject learning and English education inequality issues. This paper finds that the globalization of English leads to the globalization of other languages and cultures. It is difficult for Chinese students to choose L2 according to their interests, while unified English learning will alleviate the problem of unfair distribution of educational resources in China. This paper wishes to provide educational implications for reference for Chinese educational policymakers to formulate reforms in the future.
\end{abstract}

Keywords: English Subject Reform, China's Compulsory Education, Second Language.

\section{INTRODUCTION}

English is a world language that is widely used in many countries. As of 2011, English was spoken by 1.5 billion people around the world, about 375 millions of them are native speakers of English, which is about the same as the number who speak English as a second language; In addition, 750 million people speak English as a foreign language [1]. Especially in the 21st century, with the intensification of globalization, English, as an international Lingua Franca, has gradually become a necessary basic skill for intercultural communication. In the process of globalization, countries that are eager to gain an important position in the international market, such as China, even attempt to cultivate more international experts in various fields who are proficient in English through education to promote the further development of the national economy [2].
After the founding of the People's Republic of China from 1949 to 1984 , China borrowed the educational policy from the Soviet Union while beginning to learn Russian as a foreign language [3]. However, after the reform in 1984, Chinese students are required to learn English throughout the whole K12 learning process, and students must pass the College Entrance Examination and Graduate Student Selecting Examination with English as one of the main subjects to enter universities. Then students gradually show widespread dissatisfaction and even disgust towards English [4]. In the recent 4th Session of the 13th Plenary Meeting in Beijing, some members even proposed abolishing the compulsory English course [5]. 


\section{LITERATURE REVIEW}

\subsection{English Globalization, English as Lingua Franca}

English is currently the dominant foreign language curriculum in schools across the globe [6].

For over two decades, the dominance of English in foreign language education in China has experienced a tortuous path, which is linked to the emergence of English as a global language in the context of globalization and China's English language policy [7]. Zhang examines the varying degrees of influence of English on mainland China at the historical, educational, and political levels respectively [8]. Wang, who observes English teaching methods in Chinese higher education from the perspective of bilingual education, reveals that the globalization of English has contributed to the reform of Chinese educational curricula to meet the demand for English as a foreign language, which is one of the positive impacts [2]. China's current educational reforms are inextricably linked to English, mainly because of its power in a globalized world, of which China aspires to be a part [9]. Yang and Cai argue there is a negative impact that in the Chinese higher education sector, the internationalization of English should not be confused with globalization, but should minimize the erosion of traditional Chinese culture and avoid disconnection from local conditions and national interests [10] [11]. Another negative impact is that the Beijing Municipal Education Commission has decided to lower the marks for the English subject and to raise the marks for the Chinese subject. These two changes, which are likely to be adopted in other parts of China, will reduce the importance of English as a compulsory subject and herald a symbolic reaffirmation of Chinese over English. However, there is a positive issue that English is being used extensively in the teaching of nonlanguage subjects, particularly in elite schools, thus increasing its actual prominence. Thus, there is considerable debate about the effectiveness of Englishmediated instruction and the threat it poses to mothertongue teaching [12] [13]. A study of Chinese undergraduate students' perceptions and attitudes towards English reveal that some respondents perceived the potential value of English as a means of increasing educational opportunities and social mobility, which is developing positively. However, another group had the opinion that English language teaching was not always effective or that learning English was a waste of time and resources because most English language learners were likely not to use English after university, which was disadvantageous [14].

\subsection{Second Language Learners Learning Motivations}

Learning a second language for practical and utilitarian reasons, such as a higher salary, greater power, or a more lucrative career [15]. Reece and Walker argue that motivation is an important factor in the process of second language learning. It is emphasized that a less able student can achieve greater success [16]. Many researchers have identified two main orientations of integration and instrumental orientation in students' second language learning [17] [18]. The study of Iranian university students' motivational orientations towards learning English and their attitudes towards the target language and its community found that their attitudes towards the target language community and its members were generally very positive [19]. For economic, educational, or political reasons, people migrate to different Englishspeaking countries in search of better jobs and educational opportunities [19]. Anjomshoa and Sadighi found that teachers can directly influence students' motivation to learn English by examining the importance of motivation in second language learning [20]. Some people in China found the motivation for learning English as positive, as a means of expanding educational opportunities and social mobility. Others points to learning English are negative and ineffective [14]. They also argue that the majority of respondents were strongly motivated to learn English and believed that English would continue to be useful and important in their studies, work, and life, which they perceiving this motivation as positive and leaning towards an instrumental orientation [14].

Second language learning is a two-way affair. For example, teachers cater to the learning styles and optimize strategies of their students, and learners must do their part in achieving their second language acquisition [21].

\subsection{Other Countries or Students' Attitude of English Language Learning}

Language attitudes are an important factor in the successful learning of a second language. It usually refers to both the positive and the negative [22]. Bamghose emphasizes that many Nigerians would consider anyone who speaks such as a native English speaker to be influenced, even snobbish". Gardner and Lambert argue that there are students who feel enthusiastic about the language or who want to integrate into the culture of the language speakers who are more motivated (and more successful in their studies) than those who learn the language as a means of achieving an end (for instance, a better job) [23]. Tsuda investigated the attitudes of Japanese students in higher education towards English [24]. The data was obtained from a 
survey of over 500 Japanese university students. The results show that most students in Japan believe that English should be a compulsory subject in secondary schools. Karahan argues that positive language attitudes can lead to positive orientations of interest in learning English; conversely, negative orientations can result. Through a survey of Learning English as a Foreign Language (EFL) undergraduate students at a public university in Malaysia [25]. The results showed that students' attitudes towards learning English and using the language in all areas of use were positive. Although Malaysians generally accept and recognize English as the national second language of Malaysia and its important role as a language of communication in the context of globalization", many Malaysian students see English as a foreign language and only speak it in class [26] [27]. However, the majority of students had negative classroom instructions in their learning experience. Students' attitudes towards English language learning differed across domains in terms of areas of use and focus on learning skills [28]. Muthanna and Miao investigated the need for local Chinese students' attitudes towards the use of English Language Teaching (ELT) strategies [29]. The results showed that Chinese students did not have significant negative attitudes towards learning English, English has become the world language and it is the language of anyone who can express themselves well, which is acceptable. By reviewing the findings of a number of studies reported by educators in the field of English language teaching, this paper finds that EFL learners' attitudes towards native and non-native English teachers in EFL settings differ across contexts [30]. Dako and Quarcoo examined the relationships between Ghanaian attitudes towards English and their native language [31].

\section{METHODOLOGY}

\subsection{Participants}

In this study, we focus on the analysis of interview data. We have selected three males and three females to participate in the interview.

Table 1 lists the six interviewees of the project. Each participant was assigned a code to protect the privacy and clarify the purpose of the discussion. For example, M1 stands for male 1.

Table 1. Details of Participants

\begin{tabular}{|l|l|l|l|l|}
\hline Participants & $\begin{array}{l}\text { Country } \\
\text { of } \\
\text { Bachelor }\end{array}$ & $\begin{array}{l}\text { Country } \\
\text { of } \\
\text { Master }\end{array}$ & Major & Career Plan \\
\hline F1 & China & Malaysia & Finance & $\begin{array}{l}\text { Financial } \\
\text { Analysist } \\
\text { Teacher }\end{array}$ \\
\hline
\end{tabular}

\begin{tabular}{|l|l|l|l|l|}
\hline F2 & Canada & Australia & $\begin{array}{l}\text { Economic } \\
\text { Finance }\end{array}$ & $\begin{array}{l}\text { Financial } \\
\text { Analysist }\end{array}$ \\
\hline F3 & France & France & Economic & $\begin{array}{l}\text { Company } \\
\text { Owner }\end{array}$ \\
\hline M1 & China & China & English & $\begin{array}{l}\text { English } \\
\text { Teacher }\end{array}$ \\
\hline M2 & China & Australia & International \\
Relationship & $\begin{array}{l}\text { International } \\
\text { Media } \\
\text { Practitioner }\end{array}$ \\
\hline M3 & China & China & Dental & Dentist \\
\hline
\end{tabular}

\subsection{Data Collection}

To explore the attitudes and reasons of these participants towards reform, we chose a semi-structured one-to-one interview. Based on the above literature, we developed interview guidelines. Initial open-ended questions were used, allowing participants to relax and talk more freely about issues of concern, followed by questions that focused more on specific areas. All six interviews were conducted online, using WeChat as a tool for video calls that were recorded and lasted between 15 and 30 minutes.

\subsection{Data Analysis}

The interview data were analyzed through an iterative process of deductive and inductive reasoning [32]. First, we printed the transcribed data into four copies and sent them to each researcher. Each person pre-codes the content with a highlighter, marking and marking potentially relevant data. Regarding the literature review, we performed deductive coding on six interview records. At the same time, the topics that emerge from the data are recorded and encoded accordingly. It is an iterative process, writing code multiple times using analysis memos. Then, we compare each person's coding results, summarize the similarities and discuss the differences. It is an iterative process, writing code multiple times using analysis memos. As mentioned earlier, we also checked our initial understanding of the interview data with the participants to improve the accuracy of our analysis. Finally, we explained the data and conclusions. 


\section{ANALYSIS}

\subsection{Research question 1: What do learners think of the importance of English in China, including the globalization of English and English as an international language, and the impact of English globalization on English?}

As mentioned above, English is a compulsory subject in basic education in China. Some interviewees said that they had spent at least a decade learning English, which is not surprising since English is compulsory in China from the third grade of primary school.

\subsubsection{English Language's Status in China}

Example 1: English is the language I grew up with, I learned English for almost 15 years. (F1)

Example 2: Researcher: When did you begin to learn English?

\section{M2: Primary school.}

In some big cities, such as Beijing and Shanghai, English is even learned from the first grade.

Example 3: Researcher: When did you start learning English?

F2: I've been studying since grade one in primary school.

Among the students who started learning English in the third grade of primary school, they had been studying English for 10 years before entering Chinese universities. After entering university, students are required to pass the College English Test-Band 4 to receive their Bachelor's degrees. If students want to continue their studies, for example, to enter Chinese universities for postgraduates, they will have to learn English as it is a compulsory unified subject of the entrance examination for Chinese postgraduates. As for students who want to go abroad, most of them need to take IELTS or TOFEL exams, which means they also cannot avoid learning English. Therefore, in China, English somehow plays a crucial role in students' pursuit of academic achievement; this statement is also supported by other literature [4].

Aside from the policy emphasis, a second reason for the importance of English may be its international status. Some interviewees have expressed the high popularity of English, as well as English as an international lingua franca.

\subsubsection{English as Lingua Franca}

Example 4: Researcher: If you had the choice of which foreign language to study at the beginning of elementary school, what would you choose?

F3: English, because English is the most widely used language in the world, and it is the international lingua franca.

Example 5: Researcher: So if you had the chance to choose your favorite foreign language in elementary school, do you think you would choose English or Spanish?

M2: English, after all, is the international lingua franca. It is more useful.

Example 6: Researcher: Some people think English is useless in the future, it is just a waste of time as a compulsory course, what's your opinion?

M3: I don't agree. I think it is still very important now that many academic journals of different areas are published in English.

In the interviews, half of the participants mentioned that English is the international lingua franca and is widely used, which is consistent with Braine \& Wang's opinion [1].

\subsubsection{English VS. Other Languages}

As for the impact of the popularity of English, M2 said because English is so popular, it is difficult for other languages to replace English as another international common language:

Example 7: I think English has become so popular that it is almost impossible for other languages to replace English in international status. You can see that some international conferences are held in English and some international journals are also in English. (M2)

Interestingly, F2 argues the opposite, arguing that the globalization of English does not prevent the spread of other languages.

Example 8: I think not only English is becoming globalized, but China is developing very fast and foreigners want to learn Chinese. (F2)

Although these two participants shared some similarities in their experiences, they hold different attitudes towards the impact of the spread of English. M2's view is related to Sun et al., which states that English has cast a certain shadow on other languages [9]. But according to F2's point of view, we also cannot deny that in the process of people using English to communicate, their own cultures are spread through English at the same time, even though English is still the dominant language in the world. After all, under the background of globalization, English communications 
mostly occur between non-native English speakers and non-native English speakers who have different cultural backgrounds [33]. People are also passing on their own culture through English communication, just as F2 mentioned, globalization has brought more foreigners' attention to China.

The analysis in this section has focused on responses to questions about the importance of English and the impact of English globalization. The next session will discuss the motivation for learning English.

\subsection{Research Question 2: What are the learners' motivations to learn English in China?}

This part mainly demonstrates and discusses the results of the interview from the perspectives of Instrumental motivation and Integrative motivation.

\subsubsection{Instrumental Motivation}

Example 9: Researcher: Do you think foreign languages will be used in your future work?

F1: If I can be a teacher I think yes because bilingual teaching is very helpful.

Example 10: Researcher: Do you still think English is important after you graduate?

M2: It's also important because I'm going to work in international journalism, so I'll definitely use English.

In line with Pae, Warden and Lin, respondents believe that one of the motivations for learning L2 is its usefulness for future study and work [17] [18]. As shown, L2 exists in the future work plans of F1 and M2, the embodiment of instrumental motivation, which is similar to the research conclusion of Liu et al. [14].

Example 11: Researchers: So if you had studied French, would you have chosen French over English?

\section{F1: Right.}

Example 12: Researchers: If you studied Japanese as a child, you will also end up working for international companies, but in Japanese, right?

\section{M1: Yes.}

However, F1 and M1 point out that at present their future goals only require a language, not necessarily English. As they emphasize, they need English in their future plans simply because their previous compulsory English studies have enabled them to master English, and if they had previously been required to study French or Japanese, L2 would not be English for their future plans.
Example 13: Researchers: Do you think English is important in your work?

F3: I think English is like a degree, maybe you will not use it but you can't without it.

In addition, F3's answer seems to think that although English is important to her future goals, it is more of a function of meeting the entry requirements than actually using it daily in her work; she doesn't think she'll actually use it in her future work. This view is similar to Johnson's argument that some L2 learners learn a second language for practical and utilitarian reasons [5].

Example 14: Researchers: So as technology advances, will the need for language wane?

F1: Just for traveling, yes. If it is for a higher goal, maybe language skills still matter.

Researchers: What is the higher goal?

F1: For example, to study for a Ph.D. or do research, you need to pursue language accuracy.

Example 15: Researchers: Do you think it is feasible to rely only on translation software in your work if you don' t know English?

F2: For written work, like writing email responses, yes. But for the communication work, no, because sometimes the translation software is not polite enough.

Example 16: Researchers: So you study English for academic achievements, so for you language is just a tool?

M3: At the present stage yes.

The answers of F1, F2, and M1 seem to have some explanatory effect on F3's answer. Their view is that language, as a means of communication, is mainly used to understand the viewpoints of people who speak different languages. However, they also stress that to use a language accurately, smoothly, and appropriately, it is inadequate to rely on translation software alone but to master it yourself.

Example 17: Researchers: So does everyone need to learn to speak English?

F3: No, many people don't use it, so it is not necessary for everyone to learn it.

Researchers: Do you think people should be given the chance to learn other foreign languages if they don't need English?

F3: No. People who only know Chinese also can do a lot of work. Unless they want to conform to international standards, achieve higher achievements, and higher social status, depending on the individual pursuit. 
F3's idea seems to be an explanation of the attitude towards the reform of the only compulsory L2 status of English from the perspective of instrumental motivation: If some people think that certain L2 learning is necessary for their future development, then they should learn it; If some people do not think they need L2 for their future, then they should notbe forced to learn one.

\subsubsection{Integrative Motivation}

Example 18 : Researchers: Would you learn another language to communicate with non-native English speakers?

F2: I had this idea because it would be more cordial to communicate. I have Korean friends and have learned Korean from them.

Researchers: So is making friends a motivation for you to learn a language?

F2: Yes, it is a very important motivation for me.

Researchers: If you were given the freedom to choose a foreign language, what would it be?

\section{F2: German or Japanese.}

Researchers: Why is that?

F2: Because not many people learn German, it's special. And I like Japanese culture and I have a lot of Japanese friends so I choose Japanese.

Researchers: So what influences your choice of language is your love of culture and the influence of friends?

\section{F2: Yes.}

In addition to instrumental motivation, F2's answer also reflects her integrative motivation. Citing her own experience, she said she learned Korean because she had Korean friends. She also points out that she has many Japanese friends, which became her motivation to learn Japanese. Her example is similar to the research results of Chalak and Kassaian that L2 learners generally have positive attitudes towards target language members [19].

Example 19: Researchers: Do you use English in your daily life outside of work?

F2: Yes, I like watching YouTube and watching British and American TV shows, so that will help.

Researchers: But TV series normally have subtitles, do you still think English is needed?

F2: Yes, if I can speak English, my watching experience will be better.

In the process of transcription, we had a further discussion with F2 about her answer. She explained that when watching TV programs of other countries, although subtitles are helpful for understanding, some profound contents cannot be understood by subtitles alone. For example, some homophonic jokes can only be understood if the language is mastered. Therefore, she believes that language is the carrier of culture, and to better understand the culture of other countries, it is necessary to understand their languages. This is different from M1, which believes L2 is needed only as a communication tool.

Example 20: Researchers: Why don't you choose to learn French to understand French culture? Is it because you prefer English culture?

F1: No. Just because I learned English from my childhood.

Researchers: If you had the choice, which language would you learn?

F1: Small languages, like French.

Researchers: Why?

F1: Because I love French culture.

Although F2 points out that interests in culture is also a reason for learning languages, it seems that some Chinese students are unable to choose which language to study as Second Language(L2) based on their own interests. In this case, F2 was forced to learn a language that she was not interested in at all.

Example 21: Researchers: So you like it because you' re good at it?

M2: Generally speaking, people like what they are good at. For English, I gradually improve my English, and like its culture more as I learn it more.

Researchers: So do you like English because you have more exposure to it?

M2: English is the first foreign language that a lot of people come into contact with in China, it's kind of inevitable, so yes.

Researchers: So you were exposed to the language and then felt interested, right?

M2: Right.

Another point worth noting also seems to prove that It is difficult for Chinese students to choose which language to learn as L2 according to their own interests. M1 claims that as he is exposed to and learns more about L2, he will gradually become interested in the culture of the language. Having been exposed to English since childhood, he is interested in the cultures of English-speaking countries. Thus, it was difficult to determine whether participants who claimed to be interested in British or American culture were learning English for their own interests. From the perspective of 
integrative Motivation, it seems that the policy of taking English as the only compulsory L2 should be reformed, so that learners can have the opportunity to choose L2 from the perspective of interest and have the time and energy to learn it.

\subsection{Research Question 3: What attitudes do the learners hold towards English subject learning, including their opinion towards English education equality?}

English has essentially played the role of "Esperanto" in the current world. Most of our interviewers are concerned about the abolition of English as compulsory education in China. They also regard that English is a must-use tool in their lives and they think English education is not equal because of different regions.

\subsubsection{Student's Attitudes}

Example 22: If it is for a higher goal, you still have to rely on yourself to communicate better. (F2)

Example 23: Researcher: Do you think that compulsory education is not required to establish a foreign language, and you will not choose the foreign language you want to learn until high school. Is this idea feasible?

F1: No. Language learning is best to learn slowly from an early age to cultivate a language habit.

Example 24: Researcher: Should we abolish English as a compulsory course?

F2: Neutral, I think although it is not important, we need to master another language.

Example 25: Researcher: You think English is so important, and do you think that China needs to continue to take English as a compulsory subject now?

M2: Yes.

Example 26: Researcher: Until the college entrance examination, students are not required to learn a foreign language. Can it not only help students reduce stress, but also allow them to choose foreign languages freely in college?

F1: not supported. I think it is necessary to master at least one language first, even if I don't like it. Because hobbies always change, it is better to be prepared for language learning from childhood and to want to learn other things when you grow up.

Most interviewers have received nine years of compulsory education, and they all chose to study abroad. The applicants are also undergraduates/postgraduates from the United Kingdom, the United States, Australia, and Canada.
These countries are all English-speaking countries. International students from non-English-speaking countries need to pass TOEFL or IELTS, GRE, GMAT, and other English tests. Some programs also need Admissions officers, and for most interviewers, English is also an indispensable tool for studying abroad and living. Therefore, most interviewers believe that English as a nine-year compulsory education is still necessary.

Secondly, in the range of languages in the world, the difficulty of English is moderate for all learners. Because English has abandoned some of the complicated grammar of continental European languages in the process of its evolution, the degree of inflection has been greatly reduced. The most obvious is that English nouns and adjectives no longer have a gender category, and only retain the possessive form of biological nouns with the addition of. In terms of verbs, except for the singular third-person present tense with $\mathrm{s}$ at the end of the verb, there are no other verbs except for the person conjugation (special verbs be and have). At the same time, there are common grammatical phenomena to other European languages, such as reflexive verbs. And general pronouns no longer exist.

\subsubsection{English Education Equality}

Most interviewees believe that there is inequality in English education. For example, regional inequality.

Example 27: Researcher: So do you think there are differences in English education?

F2: Yes.

Example 28: Researcher: Do you think there is a gap between English education in Zhejiang and English education in Shanghai?

F3: Shanghai places more emphasis on communication and oral language.

Example 29: Researcher: Do you think there will be inequality between regions in English education?

F4: Existence, such as speaking: Shanghai has a more developed economy and they are more likely to go abroad, so pay attention to speaking ability. In underdeveloped areas, there are few such opportunities, so they just think about taking the test.

Researcher: Do you think that compulsory learning of English will exacerbate educational inequality between regions?

F4: Giving students the right to choose the foreign language they want without compulsory learning in English will exacerbate unfairness. Because there are not so many talents in other languages.

Example 30: Researcher: Do you think there are regional differences in English education in China? 
M2: Yes, English education is different in big cities, such as Beijing and Shanghai. They pay more attention to training students'spoken English.

All interviewers agreed that the weakening of English education may exacerbate educational inequities. Another point of view is to look at which disciplines companies take in the recruitment test, which directly reflects the actual requirements of the employer. In fact, companies seldom test Chinese and mathematics when recruiting, but test logic. Many companies test English for certain positions, including academic research positions, management positions, and certain foreign-related service industries, such as high-end Hotel service staff. Most of the best companies in China in the future will be international companies and need to manage a global team.

\section{CONCLUSION}

Through answering the three research questions, we raise three findings: the globalization of English has led to the globalization of other languages and cultures, it is difficult for Chinese students to choose L2 according to their own interests, and unified learning of English will alleviate the inequitable distribution of educational resources in China. English education in basic education has relatively high personal and social marginal effects. In particular, in the future, China needs to cultivate more international talents to become a leader in global technological and cultural innovation. Therefore, in the nine-year compulsory education, English should be abolished. In this paper, we also conclude that in English education, improving quality and efficiency and fairness are not contradictory but mutually reinforcing.

\section{REFERENCES}

[1] Braine, G. (2011). Introduction. In G Braine (Ed.), Teaching English to the world: History, curriculum, and practice (2nd edition) (pp. xi-xiii). Mahwah, NJ: Lawrence Erlbaum.

[2] Wang, P. (2017). Looking beyond the ELT approach in China's higher education from the perspective of bilingual education: immersion, content-based instruction or something else?. International Journal of Bilingual Education and Bilingualism, 20(1), 102-114.

[3] Tan, C., \& Chua, C. S. (2015). Education policy borrowing in China: has the West wind overpowered the East wind?. Compare: A Journal of Comparative and International Education, 45(5), 686-704.

[4] Liu, N., Lin, C. K., \& Wiley, T. G. (2016). Learner views on English and English language teaching in
China. International Multilingual Research Journal, 10(2), 137-157.

[5] Johnson, K. (2001). An introduction to foreign language learning and teaching. England. Pearson Education Limited. Kök, İ.(2010). The relationship between students' reading comprehension achievement and their attitudes towards learning English and their abilities to use reading strategies with regard to hemispheric dominance. ProcediaSocial and Behavioral Sciences, 3, 144-151.

[6] Hu, G. (2008). The misleading academic discourse on Chinese- English bilingual education in China. Review of Educational Research, 78(2), 195-231.

[7] Chang, J. (2006). Globalization and English in Chinese higher education. World Englishes, 25(34), 513-525.

[8] Zhang, M. J. (2007). Impact of English on Chinese Mainland: From Historical, Educational and Political Dimensions. Online Submission, 4(5), 6166.

[9] Sun, J. J. M., Hu, P., \& Ng, S. H. (2017). Impact of English on education reforms in China: with reference to the learn-English movement, the internationalization of universities and the English language requirement in college entrance examinations. Journal of Multilingual and Multicultural Development, 38(3), 192-205.

[10] Yang, J. (2000). Hong Kong higher education in transition: The academic community's perception at the time of 1997 retrocession. University of Northern Iowa.

[11] Cai, K. B. (2014). Exploration and thinking of the bilingual teaching method for signal courses. In International Journal of Modern Education Forum (Vol. 3, No. 1, pp. 13-16). Science and Engineering Publishing Company.

[12] Hu, G. (2008). The misleading academic discourse on Chinese- English bilingual education in China. Review of Educational Research, 78(2), 195-231.

[13] Tong, F., \& Shi, Q. (2012). Chinese-English bilingual education in China: A case study of college science majors. International Journal of Bilingual Education and Bilingualism, 15(2), 165182. https://doi.org/10.1080/13670050.2011.607921

[14] Liu, N., Lin, C. K., \& Wiley, T. G. (2016). Learner views on English and English language teaching in China. International Multilingual Research Journal, 10(2), 137-157. 
[15] Johnson, K. (2001). An introduction to foreign language learning and teaching. England. Pearson Education Limited. Kök, İ.(2010). The relationship between students' reading comprehension achievement and their attitudes towards learning English and their abilities to use reading strategies with regard to hemispheric dominance. ProcediaSocial and Behavioral Sciences, 3, 144-151.

[16] Reece, I., Walker, S., \& Teaching, T. (1997). Learning. A Practical Guide.

[17] Pae, T. I. (2008). Second language orientation and self-determination theory: A structural analysis of the factors affecting second language achievement. Journal of language and social psychology, 27(1), 5-27.

[18] Warden, C. A., \& Lin, H. J. (2000). Existence of integrative motivation in an Asian EFL setting. Foreign Language Annals, 33(5), 535-547.

[19] Chalak, A., \& Kassaian, Z. (2010). Motivation and attitudes of Iranian undergraduate EFL students towards learning English. GEMA Online Journal of Language Studies, 10(2).

[20] Anjomshoa, L., \& Sadighi, F. (2015). The importance of motivation in second language acquisition. International Journal on Studies in English Language and Literature (IJSELL), 3(2), 126-137. Retrieved from https://www.arcjournals.org/pdfs/ijsell/v3-i2/12.pd

[21] Hoque, M. E. (2017). An Introduction to the Second Language Acquisition. Language Acquisition, 1-23. Retrieved from https://www.researchgate.net/publication/3356908 66 An Introduction to the Second Language A cquisition

[22] Lukman, L. (2019). Language Attitudes and. Motivation for Learning Indonesian Language as A Foreign Language by Students of Malay-Indonesia Department, Hankuk University Of Foreign Studies (HUFS) South Korea. Jurnal Ilmu Budaya, $7(2), 207-213$.

[23] Gardner, R. C., \& Lambert, W.E. (1972). Attitude and Motivation in Second Language Learning. Rowley, Mass.: Newbury House.

[24] Tsuda, S. (2003). Attitudes toward English language learning in higher education in Japan (2): Raising awareness of the notion of global English. Intercultural Communication Studies, 12(3), 61-75.

[25] Karahan, F. (2007). Language attitudes of Turkish students towards the English language and its use in Turkish context. Çankaya University Journal of arts and sciences, 1(7), 73-87.
[26] Abu, B. M. R. (2013). Malaysian teachers' conceptions and uses of digital technology in English writing instruction: A multiple case study (Doctoral dissertation). Retrieved from ProQuest Dissertations and Theses. 3587444.

[27] Tom, A. A., Aiza, J., Awang, R., \& Siti, H. (2013). Factor contributing to communication apprehension among pre-university students. Academic Journal of Interdisciplinary Studies, 2(8), pp. 65-669.

[28] Ahmed, S. (2015). Attitudes towards English Language Learning among EFL Learners at UMSKAL. Journal of education and practice, 6(18), 6-16.

[29] Muthanna, A., \& Miao, P. (2015). Chinese Students' Attitudes Towards the Use of EnglishMedium Instruction into the Curriculum Courses: A Case Study of a National Key University in Beijing. Journal of Education and Training Studies, 3(5), 59-69.

[30] Sureepong Phothongsunan. (2016). Learners' attitudes towards native and non-native English speaking teachers in the EFL context. วารสาร มหาวทยาลย ราชภฏ ยะลา, $11(1), 199-216$.

[31] Dako, K., \& Quarcoo, M. A. (2017). Attitudes 。 towards English in Ghana. Legon Journal of the Humanities, 28(1), 20-30.

[32] Dörnyei, Z. (2007). Research methods in applied linguistics. New York, NY: Oxford university press.

[33] Hall, C. J. (2014). Moving beyond accuracy: from tests of English to tests of 'Englishing'. ELT Journal, 68(4), 376-385. 